\title{
University of South Australia
}

\author{
Ben Stubbs
}

\section{The night writer: The emergence of nocturnal travel writing}

\begin{abstract}
:
In 1762, the philosopher and writer Jean-Jacques Rousseau wrote in Emile (1979) that we are blind half our lives because of what we miss during the night. The notion that the night can offer a broader experience and understanding of people, culture and place is one that is particularly relevant to travel writing and travel writers, though it is a perspective that has not been widely studied. As such, this paper will explore the development of nocturnal travel writing. This awareness begins with the influence of the flâneur in Paris and London. The immersed perspective of the street wanderer inspired many writers, including Charles Dickens, who later wrote Night Walks in 1861 of his nocturnal London walking. While technology and security diminished the writers' fascination of the night in the later $19^{\text {th }}$ and $20^{\text {th }}$ centuries, it has re-emerged as an important subgenre of contemporary travel writing. There is a range of diverse examples of nocturnal travel writing in the $21^{\text {st }}$ century focusing on nature, social and cultural lives and non-English speaking countries. These examples present an opportunity to push the authentic boundaries of the travel writing form in an era of gimmicks and unimaginative storytelling. As a form which draws influence from the flâneur, psychogeography and the literary pedigree of writers such as De Quincey and Dickens, nocturnal travel writing offers the reader a new and imaginative rendering of the 'other' within different places, cultures and temporal zones.
\end{abstract}

\section{Biographical notes:}

Dr Ben Stubbs is a senior lecturer in the School of Creative Industries at the University of South Australia. He has written three books of travel writing and numerous journal articles, book chapters and features exploring the form.

Keywords: travel writing - night walking - flaneur - the 'other' 


\section{Introduction}

In 1762, the philosopher and writer Jean-Jacques Rousseau wrote in Emile (1979) that we are blind half our lives because of what we miss during the night. The notion that the night can offer a broader experience and understanding of people, culture and place is one that is particularly relevant to travel writing and travel writers despite the lack of a formidable cannon exploring its relationship with the nocturnal theme. 'Night time has remained terra incognita of peripheral concern, the forgotten half of the human experience', writes Ekirch in At Day's Close (Ekirch 2005: xxv). As such, this paper will explore the development of nocturnal travel writing and the potential it has for offering a legitimate alternative depiction of the 'other' within the form.

I will first examine the influence of the flâneur in Paris and London and the enduring impact of the immersed and on-foot perspective of the city writer. This begins with the viewpoint of Benjamin and Baudelaire in Paris and their establishment of the foundation of the city wanderer. The paper will then look at the emergence of darkness and nighttime as important literary influences in post-industrial societies. This awareness expanded the possibilities offered by the slow and methodical observational approach established by the flâneur. I will then observe the modern representation of nocturnal travel writing in a technological and illuminated world, initially within Paris and London, though more recently in a broader range of places and with more attention paid to the techniques used while capturing the nocturnal perspective. Finally, I will examine how the structure and techniques employed in nocturnal travel writing can find commonalities with different examples of experimental travel writing from the modern era to demonstrate the importance of this unusual form in maintaining an engaged and thoughtful representation of people and places.

\section{The flâneur}

'Cities, like cats, will reveal themselves at night', wrote poet Rupert Brooke (1913: 29). However, to look at the genesis of literary nocturnal walking it is useful to observe the practice of the flâneur - a person who idles, saunters or wanders around observing society - and how it gave inspiration to the broader notion of literary immersion, slow travel and the alternative perspective on city life offered by the writer on foot and at later at night. The term flâneur originated in France and was first defined by the newspaper Figaro in 1831 as a classification of those who walk the streets, not meandering necessarily, but looking for stories and anecdotes to populate their walks (Conlin 2014). It is important to note that while this term originated in Paris, it was not confined to citizens, and the flâneurie of a traveller seeing places with fresh eyes could be just as valuable. This was embodied most prominently with the work of Walter Benjamin - the philosopher and cultural critic who engaged with Charles Baudelaire's idea of the street wanderer and observer in his sprawling The Arcades Project (2002), where he examined the impact of city life on the human psyche and made the flâneur an object of scholarly interest (Shaya 2004). As Conlin writes of the development of this relationship, 'the city of the imagination weaves its web of metaphors, associations and fantasies around the actual buildings, streets and spaces' (Conlin 2014: 14) and through the initial writing of Baudelaire and then Benjamin, it was realised that the flâneur was one most adept at capturing this unique perspective of the city beyond the focus of the 
journalist or the alternate lens of the poet.

The flâneur was initially a construct of $19^{\text {th }}$ Century Paris and Shaya remarked that the flâneur was 'essential to any picture of the streets' (Shaya 2004: 47) there because of the connectedness and physical shelter offered by the busy arcades, gates and old neighbourhoods for those without a place to be. To wander like this creates a sort of intoxication when one submits to being abandoned by and absorbed within the crowd. Shaya contends that this image has endured, writing that the flâneur 'captures the experience of the modern city so well - urban alienation, the psychology of distraction provoked by the tumult of urban stimulation' (2004: 76).

During the initial emergence of the flâneur, and despite the possibilities that this awareness could occur in different places around the world through the perspective of travellers, the stories told by flâneurs essentially became part of a tale of two cities. Aside from Paris, the emergence of the literary walker in London was influenced by the writing of Thomas De Quincey, whose wanderings in the 1800 s began a broader fascination with drifting through the city streets, both during the day and later at night. De Quincey was one of the first nocturnal loiterers and much of his aimless night walking in the labyrinth of the city led to Confessions of an English Opium Eater (1821). In it he writes, 'I could almost have believed, at times, that I must be the first discoverer of some of these terrae incognitae' (De Quincey 1886: 47) in reference to the dark alleys and strange streets he encountered. It was De Quincey's walking which helped further establish the image of the flâneur across cities beyond Paris. Slightly tongue in cheek, Conlin states that 'The flâneur has been canonized as the patron saint of the nineteenth-century city' (2014: 14) due to the overuse of the term and because of the enthusiasm with which flâneurie was adopted during this period. Shaya echoes this sentiment with his question as to whether 'we have seen enough of the flâneur?' (2004: 46) because of this same overuse.

According to Wrigley though, there is scope 'to approach the flâneur in a new light' (Wrigley 2014: 9) and to re-think the boundaries of the literary walker. Shaya also writes of the need for re-thinking when he aligns the modern flâneur more with the Baudad or 'rubber necker' (2004: 50) and one who is in the streets and not of them and immerses in them only fleetingly and with voyeuristic intent.

This rethinking has been done, to a degree, with the emergence of psychogeography since the 1950s, of walking the city streets and 'catching the textual run-off' as travel writer Robert Macfarlane puts it (2005) - such as in Vanessa Berry's Mirror Sydney (2017) about her deconstruction of the city from ground level. Psychogeography is largely defined as 'the point at which psychology and geography collide, a means of exploring the behavioural impact of urban place' (Coverly 2006: 10). It has many commonalities with the flâneur while also having an enduring influence on travel writing and observational city writing more broadly.

\section{The night walker}

Journalists and literary writers provide an invaluable means of accessing the cultural underbelly of the urban night. The nocturnal wandering of Dickens in London and 
Nerval and Brettone in Paris in the $18^{\text {th }}$ and $19^{\text {th }}$ centuries allowed readers to orientate themselves in the city, 'to realign the metropolis and the mental life' (Beaumont 2015: 360). These writers were instrumental in opening up the night and deconstructing the mysteries and fears associated with it (Hussey 2008; Hazan 2011; Beaumont 2015). Other writers explored nocturnal affordances in new ways, such as Xavier de Maistre in Expédition Nocturne Autour de ma Chambre (Nocturnal Exploration Around My Room, 1825 ) and the emergence of nocturnal tourism (such as night-time nature tours along the Cliffs of Dover during the late $19^{\text {th }}$ century). With the growth of manufacturing in the city, the extension of lighting technologies and the opening up of the night to greater human activity (nightshifts, pleasure, mobilities, commerce, retail opportunities), the romantic urban night of the $19^{\text {th }}$ century became busier, less enchanting, less appealing and a new popular culture of fear emerged (Ekirch 2005).

Extending beyond the influence of the flâneur's point of view of the daytime city, many writers, including Shakespeare, Wordsworth, Dickens, Jack London and Chaucer, wrote about the combination of darkness and walking. As streetlights became more reliable in London, when five thousand oil lamps were distributed to light the nighttime, it became a place where the unchartered chaos of the dark was lessened (Stubbs 2016). Gas lamps arrived in 1807 in London (Beaumont 2015) and in the same era across much of Europe, work was extended into the nocturnal hours subsequently and there was just enough opportunity to push many writers into the streets of their now not so dark cities to explore. Beaumont notes that these writers 'used the night as a means of creatively thinking about the limits of an increasingly enlightened, rationalist culture' (Beaumont 2015: 10); the night offered these writers an opportunity to explore and temporarily inhabit a part of their city they didn't ordinarily belong within. As Blake, Clare and De Quincey were also exposed to the 'otherness' of their city in darkness, it became a compulsion for many and there was a surge in nocturnal perspectives across Paris and London.

The most prominent night walker during this time was Charles Dickens. He formed a habit of walking at night and it became a state where he could rid himself of the "dry rot in men' (Beaumont 2015: 366). Night walking allowed Dickens to enter a hypnotic state and to process his stories and the complications of his everyday life. Dickens suffered from insomnia and rather than spending the night awake, he explored London in darkness, walking the streets until he was exhausted and ready to sleep as the sun rose. He would explore the streets at night to de-clutter his mind. He did this walking all through the night hours, and satisfying this compulsion allowed him to put all these things in a filing cabinet of sorts while the quiet streets passed beside him:

Some years ago, a temporary inability to sleep, referable to a distressing impression, caused me to walk about the streets all night, for a series of several nights. The disorder might have taken a long time to conquer, if it had been faintly experimented on in bed; but, it was soon defeated by the brisk treatment of getting up directly after lying down, and going out, and coming home tired at sunrise. (Dickens 2010: 1)

It was Dickens' night walking that helped him understand himself and his city in darkness, exploring the outer limits of London's bourgeois society and 'loitering in its 
psychological and sociological borderland' (Beaumont 2015: 370). He subsequently published Night Walks as a result of these wanderings and it is still in print in 2019. Where Night Walks departed from the flâneur influence was through the intentional structure Dickens imposed on the walking - he travelled around his city, with each wandering and subsequent chapter in his book possessing a narrative purpose and goal from the offset, immersing the reader in this different point of view - just as a piece of travel writing would immerse us in an unfamiliar city. The chapters are: 'Night walks', which introduces the reader to Dickens' insomnia and his walking compulsion; 'Gone astray', which details the sensation of being lost, at night, when he was a child and the influence this has on the adult night walker; 'Chatham Dockyard', on his encounter with a young boy by the river and the impulse to explore the imposing docks in greater detail; 'Wapping Workhouse', in the winding dirty alleys to investigate the plight of young women in the destitute establishment; 'A small star in the east', where he writes about a hospital established by young people; 'On an Amateur Beat' examines the city's homelessness; 'Betting-Shops', about the social ills of gambling, and 'Trading in Death', on the commodification of death. Dickens writes that even the 'idlest walk must always have its appointed destination' (2010: 10). Sutherland writes of Dickens' nocturnal approach: 'In Night Walks Dickens uses personification and striking analogies that highlight rather than mask the darkness, homelessness, drunkenness and misery' on his structuring of the London night (Sutherland 2011).

Interestingly, Dickens was fascinated by the period between $2 \mathrm{am}$ and $4 \mathrm{am}$, which he labelled 'the dead of night' (Beaumont 2015: 353), which contained an 'existential or spiritual category' (Beaumont 2015: 353) during the deepest and darkest hours of the night and the period most removed from our understanding and comfort zone. For Wordsworth, who was a close friend of De Quincey, and who walked the roads of the Lake District at night, this same 'dead of night' perspective also created a form of rhythmic hypnosis where his night walking allowed him to develop his half-formed ideas into poems. Beaumont highlights that Wordsworth's most famous poem, The Prelude 'is pleated throughout with important, if not epiphanic, incidents that take place at night when he is on foot' (Beaumont 2015: 232).

Beaumont's fascination with the development of the night walker is explored in his analysis of the history of English nocturnal wandering in his 2015 book Night Walking: 'Nightwalking is, in both the physical and the moral meanings of the term, deviant' (Beaumont 2015: 5). Beaumont's theory comes from a long history of suspicion throughout Europe at those who stalk through cities at night. Beaumont notes that night walking was seen as a sign of moral, social or spiritual dereliction and as far back as the Middle Ages, it was recognised as a criminal activity. In the late $12^{\text {th }}$ century the presence of 'actors, jesters, smooth-skinned lads, moors, flatterers, pretty-boys, effeminates' (2015: 16) highlighted the unsavoury characters you could expect to encounter if you were caught wandering through London at night. These walkers were called 'noctambulators', those with voyeuristic intent, and prior to the year 1500, men caught wandering the streets were called 'noctavigators', those with a lack of means or a criminal intent, and punished accordingly. The general thought being that if you are alone at night and on the street without a commendable purpose, then you surely must be up to no good. 
According to Ekirch, many early civilisations did not fear the darkness, though they feared the perils that arose within the darkness. Thus, night eventually became synonymous with danger and the instinctive terror of the night has grown from this interpretation and these early people who may have encountered prowling beasts, battering winds or maybe just their own imaginations thousands of years ago. Ekirch writes that night 'was man's first necessary evil, our oldest and most haunting terror' (2005: 3). Observers of the night, as early as Aristotle, commented on the fear night brings in children as young as two, as if it is instinct rather than cultural conditioning which develops this sensibility. Ekirch writes of the fearful place the night once held before electricity and streetlights:

Rather than a backdrop to daily existence, or a natural hiatus, night time in the early modern age instead embodied a distinct culture, with many of its own customs and rituals. As a mark of its special nature, darkness in Britain and America was frequently known as the "night season". (2005: xxv)

This night season became something that inspired and intrigued writers across Europe, though just as with the flâneur, this nearly exclusively centered on the exploration of the dark streets of Paris and London.

Restif de la Brettone, a writer who was '[m]elodramatic, self-obsessed and prone to lofty, moralizing statements' (Hussey 2008: 184), presented an alternative perspective of Paris, with his Les Nuits de Paris (The Nights of Paris) published in 1789. He would walk the lonely streets in search of vices to satisfy his urges, though he maintained that his underlying motive was to 'Uncover the dark side of the city so it could literally be moved towards the light' (Hussey 2008: 186). As Hazan reports in The Invention of Paris: A History in Footsteps, Restif was the 'first to describe the pleasure of night time wandering in this Paris populated by beggars, whores and thieves and the intoxication that takes hold of someone who has walked for a long while quite alone, and aimlessly, just following the streets' (Hazan 2011: 319).

The development of Paris as an emerging location for nocturnal travel writing was continued by philosopher, poet and writer Gerard de Nerval. In French Romantic Travel Writing: Chateaubriand to Nerval, Thompson looks at the importance, and scarcity, of exploring place psychologically as well as physically during darkness.

Nerval embraced the possibilities of chance and caprice with his 'extreme' nocturnal wandering in Paris. In 1852, he published a book on his impressions of Paris at night. Hazan also detailed Nerval's relationship with, and journeys through the night in the city as he captured the 'first precise description of the atmosphere' (Hazan 2011: 320) writing, as if a travel writer, of the markets at night, of oyster bars, his observations of rich men disguised as peasants, fights between greengrocers and fishmongers, ragpickers and all-night cafes. He also wrote of the fantasy and 'hallucinated wandering' (Hazan 2011: 320) produced by his walks while observing the changes in his preferred district of Montmartre as a 'different city was emerging' (Hazan 2011: 321) from the night.

As the cities became lighter, though, through the push of technology and capitalism, the writer's fascination with the world of the street at night lessened and there were fewer 
prominent examples of writers exploring their cities at night in great depth until the early $21^{\text {st }}$ century (Stubbs 2016: XVII).

\section{The modern nocturnal travel writer}

Until recently, the nocturnal perspective within the modern era of travel writing has largely been ignored. Unsurprisingly, the recent examples of the re-emergence of this genre began with a focus on Paris and London once again. Most notable of these is Sukdev Sandhu's Night Haunts (2007), which explores the modern London nocturnal reality using a flâneur-like lens to look closer at the aspects of the city many citizens don't see. Sandhu separates his book into chapters focusing on different groups of people: from helicopter police on patrol, to night-cleaners, urban foxhunters and sleep technicians, all with a focus on places away from the $21^{\text {st }}$ century intrusions of CCTV and street lighting. Particularly interesting in Sandhu's book is the concentration on the quieter hours of the night after $2 \mathrm{am}$, where 'fear and sadness and regret rack up so that it becomes impossible to get to sleep' (2007: 40) and there 'is nothing to be done at $3 \mathrm{am}$ except hold on'. This is similar to Dickens' fascination with that same period - the dead of night - with its strange and spiritual qualities. Sandhu's writing is poetic and ethnographic, giving a voice to migrants, nuns and ambulance drivers on night shifts, among others, to expand our understanding of what London is and to hear 'the sound of London's heart beating' (2007: 140) through the representation of the city after dark in the $21^{\text {st }}$ century.

While Sandhu's Night Haunts offers a unique and modern re-writing of the London night beyond the perspective of Dickens, there has been recently expanded attention on the night beyond solely London and Paris, with Chris Yates' Nightwalk: A journey to the heart of nature (2014) on nocturnal nature walking in the British countryside, Ian Marchant's exploration of night culture in the British Isles in Something of the Night (2012) and my own After Dark: a nocturnal exploration of Madrid (2016) on the streets of night-time Madrid.

Yates' Nightwalk is unique on this list as it focuses on nature writing and the nocturnal perspective outside cities altogether. He has lived in the rolling hills around Cranbourne Chase in the UK for more than 25 years and is drawn to walking through the fields, under trees and beside the lonely streams after dark: 'Uninhabited, of course except for the local fauna' (Yates 2014: 13). Yates writes of the different nocturnal focus of his book. He is able to observe and describe the incredible animal life he encounters in the countryside in the dark because of his distinctive approach: 'I go quietly and never carry a torch, I only ever meet the true natives' (2014: 12). Animals fascinate Yates (he has published previously on fishing) though the impulse to write about nature in this unusual temporal setting is one that has been within him for more than forty years. He states, 'I first sketched an outline for a book about the night in 1971' (2014: 211), demonstrating the same compulsion that has drawn many writers to explore the night. Because he is outside the city and wandering in a much truer darkness than the city walkers, he encounters a very different reality. He walks among deer, owls, rabbits, stars and the natural environment in a way which is quite foreign and unique when compared to previous nocturnal writing that focuses on cities where, even in the darkest 
corners, there are still street lights, security cameras and signs of people's footprints on the city.

Yates 'strolls' (2014: 9), often blindly in the night as he travels through the countryside, across fields and along quiet lanes. While he comments on being scared of the dark initially as a child, the promise of foxes on cold winter nights or serpents in his dark back garden (where he eventually encounters scores of lizards) plants the seed of fascination rather than fear, which is evident in his writing and his enthusiasm for the nocturnal perspective throughout Nightwalk. Yates uses the diary-like perspective of capturing one entire night, from the moment he leaves his kitchen after dark until he arrives back home on a wet Monday morning to his house: 'I came down the final slope, where the trees overhang my house, walked through the small wilderness of garden and quietly, because people were still asleep upstairs, let myself in' (2014: 212). As an interesting example of the conditioning children receive to be wary of the night, and a theme which is also echoed in the writing of Dickens and Ekirch, Yates has taken a different approach with his nature wandering and how he opens up the night for his family as well: '[M]y children, too, by accompanying me on moonlit jaunts when they were very young, soon overcame their instinctive fear of the dark and would go on nocturnal adventures of their own' (2014: 12). This notion of conditioning is interesting when considered in a historical context. As so much of the perspective of the night has been seen as one to shut out, avoid or as a transitional phase within the 'real' narrative of travel texts, rather than a space to embrace and illuminate, as Yates does for his children, it offers a suggestion as to why there has been a lack of the nocturnal travel writing perspective previously.

In Marchant's Something of the Night (2012) he adopts the same curiosity and creative approach as Sandhu, though his writing is centred on people and the possibilities the night enables, both fantastical and mundane. Marchant also focuses on the humour that the night conceals and enables. He begins:

When I was a kid, anything could happen in the night. It very seldom did; but it could. I could play centre-back for Brighton and England. I could replace Macca on the bass guitar in the re-formed Beatles. I could say "Hello" to Jackie Sinclair, the girl of my dreams. (Marchant 2012: 2)

His journey into the night begins in West Cork with an old friend and a night of beer and marijuana, before he digresses into his early memories of night and sleep, of the history of the Mass Observation movement and market research into sleeping habits and the history of English mattresses - from his recollections of his parents sleeping on straw bedding in his youth to the $17^{\text {th }}$-century preference to use moss and beech leaves to find rest during the night.

Marchant presents the night as a place of adult freedom and possibility: '[N]ight is our time of greatest playfulness and freedom, of love and romance. We go to pubs, clubs and all-night drinking dens; we go to cinemas, theatres and bingo halls' (2012: 5). Marchant taps into the important duality of the night - and its external perception - by acknowledging that night, still, is 'the time of our greatest fears: of ghosts and ghouls, and vampires, and werewolves, of night terror and night sweats' (2012: 6). He also raises a more contemporary concern about the metropolitan night and the politics 
around the Night Time Economy - the movement to commercialise the night with bars, chain drinking establishments and middle-class entertainment venues and events that focus on the consumption of alcohol. 'The night has become heavily politicised, as the idea that inner-city areas are given over to drunken youth blossoms unchecked in the press and broadcast media' (2012: 5). Though Marchant is clear to point out that while much of our modern focus on the night is of alcohol, sleaze and commercialism, the positive associations of recuperation, dreams and the wonder of the night are often forgotten. Marchant suggests that this deserves closer attention and it is a space worth inhabiting and exploring in greater detail.

In my own book After Dark: a nocturnal exploration of Madrid, I was mindful of the writing that had come before me (on London and Paris), and thus it prompted me to explore the nocturnal story of Spain's capital at night and on foot, travelling through the city in darkness:

Rousseau's statement that we are blind half our lives because of what we miss in the night resonates again. If we, writers, travelers and researchers are blind for half of our lives, even in the $21^{\text {st }}$ Century, I wonder what it is we're missing? (2016: 13)

My intention for After Dark was that it has the potential to add 'another layer, another lens, to the stories of Madrid and the experience of the night for visitors in the city' (2016: 6). To expand upon the writing of those before me, both thematically and creatively, I decided to utilise the 'contract of truthfulness' (Youngs 2005) as coined by travel writer William Dalrymple to extend the possibilities of the perspective and to enable the narrative to flow more easily for the reader. The process was meticulous and it took many weeks to complete, though each chapter is constructed as a self-contained hour within the night and it allows segmented and focused attention on one part of the city for each hour - on the history of bullfighting, life in the poorer barrios, of tourism and hedonism and of the simple act of walking along a darkened city street with a local to hear their story. Thus the book begins as the sun goes down at $7 \mathrm{pm}$ with a flâneuresque walk in the outer suburbs alone and it gradually winds through the city until 7am when the sun rises once again and I arrive on the cobblestones in an unheralded central lane where the story of modern Madrid is said to have begun.

\section{Technique and influence}

Beyond charting the historical progression of nocturnal writing from the flâneur to present day travel writing, it is also worth looking at how this night-time perspective has the potential to add to the canon from a content point of view.

There is something important about the perspective offered by the night from a traveller's perspective. If, as Casey Blanton writes, travel writing is a 'vehicle whose main purpose is to introduce us to the other' (Blanton 1997: xi) then there is an opportunity for a rendering of the night to expand upon this perspective. Many theorists have written on the representation of the 'other' in travel writing, and most often, this refers to the way cultures and whole groups of people are categorised by visiting writers. Renowned Polish travel writer and war reporter Ryszard Kapuscinski 
challenged this when he wrote: "the terms "Other" or "Others" can be understood in all sorts of ways and used in various meanings and contexts' (Kapuscinski 2008: 22). There has been much written about the Grand Tour, the Golden Age of travel, colonial representations and the 'other' with the early explorers' versions of everywhere from South America to the Pacific. What about travel writing and the nocturnal perspective offering an important alternative to the increased gimmicks with the form, and as a legitimate method for further exploring place, culture, difference and the 'other' from a unique position? Couldn't this also refer to the perspective of the people and places during the night when most other travel narratives are focused on daylight narratives?

If the majority of travel narratives are set during the day, and the night is often used as a transition or a time when danger or clandestine themes appear (sex, drugs, infidelity, overnight travel and violence), then travel writing has an opportunity to expand the perspective of the 'other' by writing about the people and places of the night as a central theme. Capturing place after dark doesn't require the use of literary tricks to convince the reader of the worthiness of the narrative as some travel books seem to now employ as with Do Travel Writers Go to Hell? (2008), where Thomas Kohnstamm conjures risk and gonzo-personality in a laborious fashion in order to have a blurb and a dust jacket that will entice readers, when his original premise, to question and examine the veracity of guide books, is actually quite important. These motives are dangerous to travellers and places, their representation, and the broader reputation of the genre.

To counter the emergence of gimmick in modern travel writing as seen with Kohnstamm and contemporary examples such as Tony Hawks' Round Ireland with a Fridge (2001) or A Piano in the Pyrenees (2006), and as a way of pushing past the staged scenarios emerging in the relationship between travel writing and tourism and even 'dark travel writing', the theme of travel writing at night seems a remarkably simple concept which could allow a more inclusive representation of place and the 'other'.

This sort of simplistic approach which challenges the construction of travel writing does have historical precedent. Xavier de Maistre wrote Voyage autour de ma chamber ( $A$ Journey Around my Room) (1794) after being imprisoned in his room for six weeks when he was caught fighting a duel in Turin in 1790. He observed the form through a different lens to give the reader an alternate perspective on what travel writing could be without sacrificing integrity. As an interesting side note, de Maistre followed up this work with Expédition nocturne autour de ma chambre (A Nocturnal Expedition Around My Room) (1825) to further push the boundaries of the form by concentrating only on the night-time perspective of his travel narrative within his room. Here de Maistre decides to take the readers along to 'revisit the country which I had formerly so delightfully travelled through' (2015: 7) where they can appreciate the view across to other apartments and share with him his thoughts on love and loneliness while imagining what those inhabiting the windows across from him might be doing during the night. He presents this different perspective as 'another country' within his travels, where the simplest alterations and vantage points can alert us to whole other worlds to explore.

As de Maistre writes, this 'other' perspective of the night is worth exploring and 
inhabiting as both writer and reader. The nocturnal perspective in travel writing can offer an alternate rendering of place. It can act as an investigational and progressive theme to provide a sense of newness which experiments with the expectations of the form and challenges readers through a creative combination of the geographic and temporal.

\section{Conclusion}

In Orientalism, Said wrote that lazy and dangerous writing about the Orient had become 'a function of learned judgment' (Said 1978: 67) relying on the authority of past accounts rather than criticising and observing situations for their uniqueness. Said notes that the notion of the 'other' was qualified further by the 'sizeable body of literature produced by novelists, poets, translators and gifted travellers' (1978: 40). He admits that there is a need to study 'contemporary alternatives' (40) in order to find new ways of writing about the 'other' and that travel writing can fill an importance space in doing this. The reliance on past images and learned judgments is something that has also crept into many aspects of contemporary travel writing, from the use of gimmicks to the unimaginative re-presenting of place and people. Promoting the nocturnal perspective could go some way towards exploring place and the 'other' from a more engaged and thoughtful position.

This paper has sought to establish the origins and influences of nocturnal travel writing through the identification of the flâneur in Paris and London and the initial writing of Walter Benjamin. It then charts the various writers and journalists who turned their attention from solely metropolitan city wandering to the perspective of the night and the additional layer darkness could add to a writer's understanding of place. This occurred most notably in Paris and London during its early manifestations, with Charles Dickens' Night Walks becoming particularly influential.

As capitalism and technology lessened the mysteries of the night during the $19^{\text {th }}$ century, literary attention on the nocturnal also diminished. Recently, in the late $20^{\text {th }}$ and early $21^{\text {st }}$ centuries there has been a renewed vigor for writing about the night which has extended beyond the confines of solely Paris and London. The perspective of the modern city offered by Sandhu, of the British Isles by Marchant, of nocturnal nature by Yates and of Madrid from my own work, all offer alternatives and new perspectives of place, people and the cultures being written about.

Nocturnal travel writing has the opportunity to expand on Benjamin's initial idea of the flâneur. Nocturnal travel writing can also allow modern writers to address Said's call for a more engaged rendering of place, by focusing on the night and exploring who lives there, what it looks like, how it differs from the day time, and that it is not a place to be feared, but a manifest new half of our lives, our cities and our neighbours to discover.

\section{Works cited}

Alvarez, A 1995 Night, Norton, New York

Baudelaire, C 2009 Le Spleen de Paris (trans K Waldrup), Wesleyan University Press, Middletown CT 
Beaumont, M 2015 Night Walking: A Nocturnal History of London, Verso, London

Benjamin, W 2002 The Arcades Project, Harvard University Press, Cambridge

Berry, V 2017 Mirror Sydney, Giramondo Publishing, Sydney

Blanton, C 1997 Travel Writing: the self and the world, Psychology Press, London

Brooke, R 1913 Letters from America, Charles Scribner's Sons, New York

Conlin, J 2014 “"This Publick sort of obscurity”: The origins of the flâneur in Paris and London, 1660-

1780', in R Wrigley (ed) The flâneur abroad: historical and international perspectives, Cambridge Scholars Publishing, Cambridge: 14-40

Coverley, M 2010 Psychogeography, Pocket Essentials, Harpenden

De Maistre, X 2015 A Journey Round My Room (+ a Nocturnal Expedition Round My Room) (trans H Attwell), Hurd \& Haughton, New York

De Quincey, T 1886 Confessions of an English Opium-Eater, George Routledge \& Sons, London

Dickens, C 2010 Night Walks, Penguin Books, London

Ekirch, A 2006 At Day's Close: Night in Times Past, Norton, New York

Hawks, T 2001 Round Ireland with a Fridge, St Martin's Press, New York

Hawks, T 2006 A Piano in the Pyrenees, Ebury Press, London

Hazan, E 2011 The Invention of Paris: A History in Footsteps, Verso, London

Hussey, A 2008 Paris: The Secret History, Bloomsbury, London

Kapuscinski, R 2008 The Other, Verso, London

Kohnstamm, T 2008 Do Travel Writers Go to Hell?, Broadway Books, New York

Macfarlane, R 2005 'A Road of One’s Own’, Times Literary Supplement (7 October): https://www.thetls.co.uk/articles/private/a-road-of-ones-own/ (accessed 2 March 2018)

Marchant, I 2012 Something of the Night: A Journey in the Darkness of the British Isles, Simon \& Schuster, New York

Rousseau, J 1979 Emile, or On Education (trans A Bloom), Basic Books, New York

Said, E 1979 Orientalism, Vintage Books, New York

Sandhu, S 2010 Night Haunts: A Journey Through the London Night, Verso, London

Shaya, G 2004 'The Flâneur, the Badaud, and the making of a mass public in France, circa 1860-1910', American Historical Review 109, 1: 41-77

Stubbs, B 2016 After Dark: A nocturnal exploration of Madrid, Signal Books, Oxford

Sutherland, E 2011 Review of Night Walks, Text: Journal of writing and writing courses 15, 1:

http://www.textjournal.com.au/april11/sutherland_rev.htm (accessed 22 April 2018)

Thompson, CW 2011 French Romantic Travel Writing: Chateaubriand to Nerval, Oxford University Press, Oxford

Wrigley, R 2014 'Introduction', in The flâneur abroad: Historical and International Perspectives, Cambridge Scholars Press, Cambridge

Yates, C 2014 Nightwalk: A Journey into the Heart of Nature, William Collins, London

Youngs, T 2005 'Interview with William Dalrymple', Studies in Travel Writing 9, 1:

https://www.tandfonline.com/doi/abs/10.1080/13645145.2005.9634966 (accessed 16 May 2018) 